\title{
Correction to: Microbiomes attached to fresh perennial ryegrass are temporally resilient and adapt to changing ecological niches
}

Sharon A. Huws ${ }^{1,2^{*}}$, Joan E. Edwards ${ }^{2,3,4}$, Wanchang Lin², Francesco Rubino ${ }^{1}$, Mark Alston ${ }^{5}$, David Swarbreck ${ }^{5}$, Shabhonam Caim ${ }^{6}$, Pauline Rees Stevens², Justin Pachebat ${ }^{2}$, Mi-Young Won ${ }^{1}$, Linda B. Oyama ${ }^{1,2}$, Christopher J. Creevey ${ }^{1,2+}$ and Alison H. Kingston-Smith ${ }^{2+}$

\section{Correction to: Microbiome 9, 143 (2021)}

https://doi.org/10.1186/s40168-021-01087-w

Following the publication of the original article [1], it was noticed that the figure image of Fig. 6 should be for Fig. 3 . The image for Fig. 3 should be for Fig. 5 and Fig. 6 was missing. The correct Fig. 6 have been provided below and the original article has been updated to correct Figs. 3, 5 and 6 .

\section{Author details}

${ }^{1}$ Institute of Global Food Security, School of Biological Sciences, Queen's University Belfast, 19 Chlorine Gardens, Belfast, Northern Ireland BT9 5DL, UK. ${ }^{2}$ Institute of Biological, Environmental and Rural Sciences, Aberystwyth University, Aberystwyth SY23 3FG, UK. ${ }^{3}$ Laboratory of Microbiology, Wageningen University \& Research, 6708 Wageningen, WE, Netherlands. ${ }^{4}$ Current work address: Palital Feed Additives, Velddriel, Netherlands.

${ }^{5}$ Earlham Institute, Norwich NR4 7UH, UK. ${ }^{6}$ Quadram Institute, Norwich NR4 7UA, UK.

Published online: 10 August 2021

\section{Reference}

1. Huws SA, Edwards JE, Lin W, Rubino F, Alston M, Swarbreck D, et al.

Microbiomes attached to fresh perennial ryegrass are temporally resilient and adapt to changing ecological niches. Microbiome. 2021). https://doi. org/10.1186/s40168-021-01087-w;9(1):143.

The original article can be found online at https://doi.org/10.1186/s40168021-01087-W.

*Correspondence: S.huws@qub.ac.uk

${ }^{+}$Christopher J. Creevey and Alison H. Kingston-Smith contributed equally to this work.

'Institute of Global Food Security, School of Biological Sciences, Queen's University Belfast, 19 Chlorine Gardens, Belfast, Northern Ireland BT9 5DL, UK ${ }^{2}$ Institute of Biological, Environmental and Rural Sciences, Aberystwyth University, Aberystwyth SY23 3FG, UK

Full list of author information is available at the end of the article

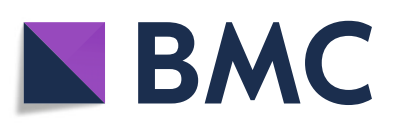

( ) The Author(s). 2021 Open Access This article is licensed under a Creative Commons Attribution 4.0 International License, which permits use, sharing, adaptation, distribution and reproduction in any medium or format, as long as you give appropriate credit to the original author(s) and the source, provide a link to the Creative Commons licence, and indicate if changes were made. The images or other third party material in this article are included in the article's Creative Commons licence, unless indicated otherwise in a credit line to the material. If material is not included in the article's Creative Commons licence and your intended use is not permitted by statutory regulation or exceeds the permitted use, you will need to obtain permission directly from the copyright holder. To view a copy of this licence, visit http://creativecommons.org/licenses/by/4.0/. The Creative Commons Public Domain Dedication waiver (http://creativecommons.org/publicdomain/zero/1.0/) applies to the data made available in this article, unless otherwise stated in a credit line to the data. 


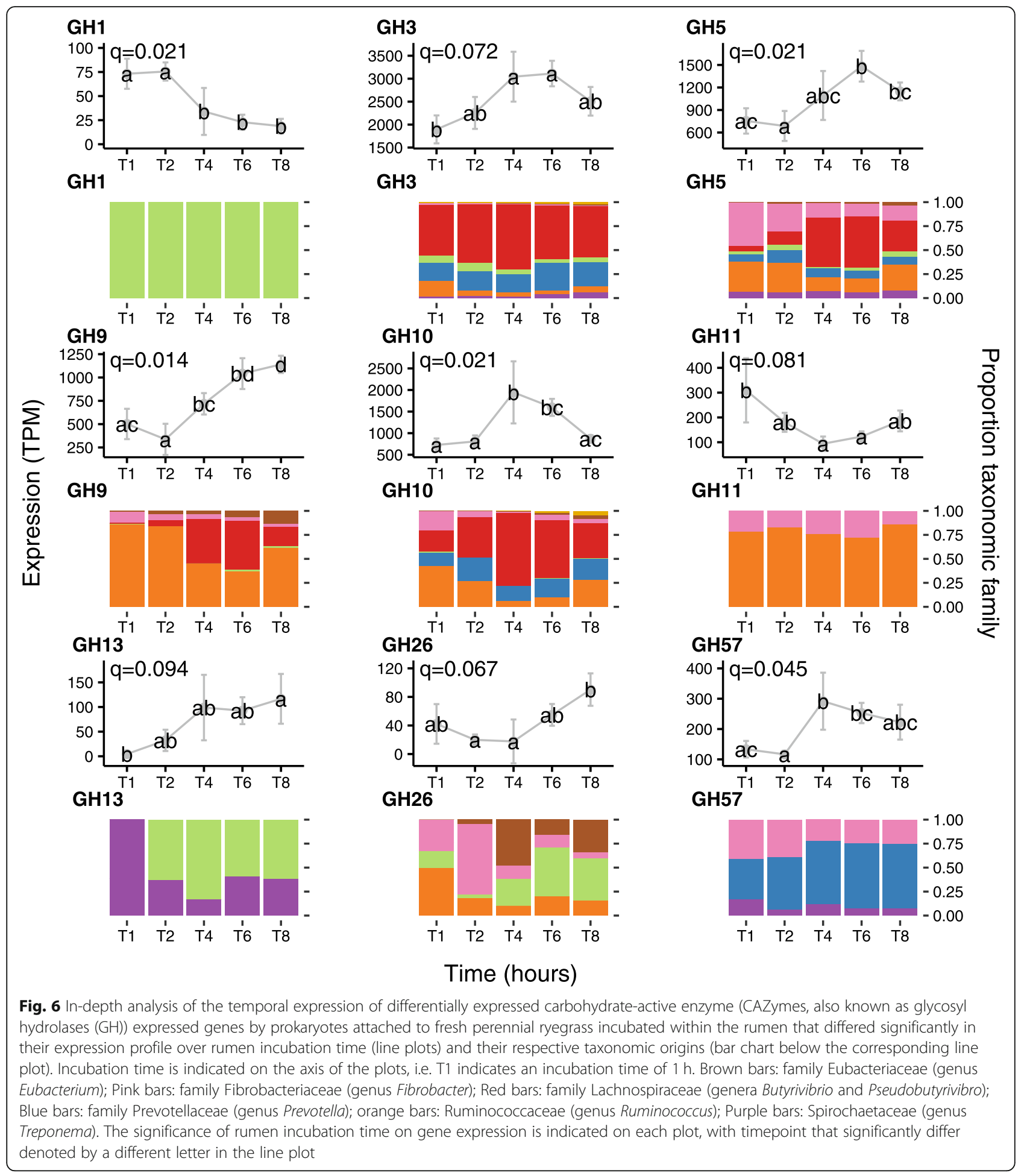

